\title{
A Limited Express or Stopping All Stations? Railways and Nineteenth-Century New Zealand
}

\author{
ANDRÈ BRETT ${ }^{1}$
}

\begin{abstract}
Railways have been a significant part of New Zealand life, yet their treatment in historiography often does not reflect this. I argue for a greater appreciation of railways, focusing upon their role in shaping the developing colony in the nineteenthcentury. I introduce the existing literature to indicate contributions with which greater engagement is required and to identify directions requiring further research. The provincial 'prehistory' of railways preceding the Vogel boom of the 1870s requires particular emphasis; railways figured prominently in the settler imagination even though physical construction was minimal. I then show that the forces unleashed by Vogel were more than economic and offer tentative conclusions regarding the railway's role within a range of fields. The railway was a site for contesting morality, it deepened the colonial project and identity, and it defined the contours of daily life.
\end{abstract}

The history of railways - and of other forms of infrastructure and transportation - has not always received its due. Enthusiasts have been unfairly pigeonholed as 'anoraks' or 'foamers', language that implies drab, boring, and somewhat obsessive tendencies. Within academia, the scholarly worth of studying railway history has not always been viewed as particularly great. However, I would like to argue for the significance of railways within the broader framework of New Zealand history. This article is less a comprehensive historiographical survey than a modest exploration of poorly understood facets of New Zealand's railway history, offering some tentative conclusions. It deals with the nineteenth-century, when the system was formed, and particularly the provincial era between 1853-76, as this phase is most poorly understood of all. I first introduce a selection of the literature, including valuable contributions from outside the national historical narrative with which scholarly engagement has been limited. This indicates directions of research that are discussed in the rest of the article. I place particular emphasis on the provincial 'prehistory' of railways, which contextualizes the Vogel boom after 1870 , and the increasingly pivotal and complex role of the railway in New Zealand society in the final three decades of the nineteenth-century.

New Zealand is a rare example of a settler society founded after the invention of the railway, and consequently it has a foundational intersection of railways with national development, society, and politics. Michael Freeman's innovative argument that railways were a 'cultural metaphor' and 'social phenomena' in Victorian Britain is just as true for New Zealand. Railways were 'deeply embedded in the evolving structure of Victorian society ... [and] enmeshed in the spirit of the age'. ${ }^{2}$ They were crucial to the colony's growth and absorbed a large portion of its public investment, functioning as a prominent component of what James Belich calls the 'progress industry', an 'interacting complex of economic activities ... centred on growth and development'. ${ }^{3}$ No understanding of New Zealand in the nineteenth-century can be complete without comprehension of both how the railway was conceptualized and how it shaped political, social, and economic life. I also wish to emphasize Peter Gibbons' suggestion that "New Zealand" is a discursive construction, a shorthand device for referring to a multiplicity of places, peoples, products, practices and histories' ${ }^{4}$ New Zealand did not emerge as a fully formed nation-state with the signing of the Treaty of Waitangi, and as Tony Ballantyne stresses, 'the nation-state has frequently been deployed anachronistically'. 5 New Zealand of the provincial and immediately post-provincial era was not one polity but at least 
ten loosely grouped together in a quasi-federal system - I say 'at least ten' in light of the numerous hinterlands with aspirations to independent provincial life that never secured a divorce from their provincial capital prior to abolition of the provinces in 1876. It is, at any rate, hard to deny John Cookson's argument that localism and local identity were potent forces that were nurtured during the provincial era and retained considerable strength until well into the twentieth-century. ${ }^{6}$ Railways were crucial to the national project; they were also central to ideas of locality and politics in this period.

However, much of the existing literature on New Zealand's railway history is written from an amateur perspective for the enthusiast market, and it is yet to be integrated into academic narratives in a satisfactory, detailed manner. This is compounded by the unwarranted assumption from some historians that the railway has already received satisfactory treatment. Rollo Arnold, for instance, suggests the railway's 'impact is well recorded in our national, regional and local histories', receiving 'pride of place' within them. ${ }^{7}$ I shall show that this is largely untrue and that the railway has been more significant than its typical representation would indicate.

In saying this, I do not wish to downplay the existing literature. The position of railways within New Zealand's labour history has not fared badly, most notably thanks to Erik Olssen's work on Dunedin's Hillside Workshops. ${ }^{8}$ Valuable case studies by David Hamer, John Rosanowski, and Russell Stone provide important regional examples of the links between politics, business, and railways. ${ }^{9}$ These have inspired only limited investigation into the national role of infrastructure in New Zealand statecraft, even though J.A. Dowie has shown that railways were the single most significant component of public capital formation after 1870. ${ }^{10}$ A bright spot is Hamer's example of how the Liberal Party carefully managed internal tensions and social unease in the late 1890s with regards to the resumption of overseas borrowing for railways and other infrastructure. ${ }^{11}$ It shows the potential of railways to provide deeper understanding of the interaction between political objectives and social attitudes.

Most significantly, Neill Atkinson has taken important steps towards studying the role of railways within Pākehā society in his outstanding book Trainland. ${ }^{12}$ Also important is Ballantyne's re-assessment of colonial New Zealand's historiography, in which he notes that transportation networks shaped the modern nation, both investing power in the central government and creating uneven outcomes through the inconsistent pace of expansion and gaps in the networks. ${ }^{13}$ I draw upon Ballantyne's study, but unfortunately his engagement with railways lasts less than a page. On a less academic level, David Leitch and Brian Scott present thorough research on the remnants - or 'ghosts' - of closed railway lines. ${ }^{14}$ Although by no means purporting to construct a coherent narrative, Leitch and Scott touch on important themes of the railway's economic and social role when discussing how certain lines came to exist and why they closed, often highlighting the local pressures that influenced the shape of the national network.

The enthusiast literature mostly privileges narrative and photographic accounts. Lavish works of photography have been produced for such a marginal market. ${ }^{15}$ Nostalgic accounts of steam locomotion are popular, and multiple authors have compiled records of locomotives - when they were built, where they operated, and whether they have been preserved. ${ }^{16}$ Histories of the network, or of individual lines within it, tend to focus on discrete opening and closing dates, rollingstock used, and other details of interest to railfans. ${ }^{17}$ These are undeniably valuable, both for their admirable attention to detail and their encouragement of the historical interest of audiences rarely engaged by academics, but they do little to illuminate how technical details and narrow case studies fit into history more broadly. Where is the intersection between railways and colonization, railways and politics, railways and the 
wider economy, or railways and the settler imagination? To take just one example, the development of the $\mathrm{K}^{\mathrm{B}}$ class steam locomotives to tackle the Midland Line between Christchurch and Arthurs Pass is fascinating for the technically minded or anybody impressed by the force and majesty of steam locomotion, but it does not speak to the role of railways in forming modern Canterbury. The near mythologizing of some locomotives and railway lines has often been conducted in an ahistorical manner. The existing literature provides a firm chronological foundation and copious technical detail - what is needed now is to study how that development and evolution influenced and was influenced by New Zealand's national and regional polities, economies, and societies. Here I respond to Ballatyne's encouragement that we should 'place much greater importance on the role of transport and communications in dictating the contours of the colonial economy, in shaping the rhythms and routines of colonial cultural life, and in shaping the specific social formations that emerged in each locale and district'. ${ }^{18}$

This article must unfortunately overlook the role played by urban tramways in the history of New Zealand's cities. Bush tramways, although not covered in depth, make an appearance, but space prohibits a discussion of their urban counterparts. Although not as influential as the railway, trams played a part in the development and social patterns of New Zealand's cities - both major and regional - from the 1870s until the last system, Wellington's, closed in $1964 .{ }^{19}$ Indeed, the negative consequences of tramway closures upon New Zealand's urban history, especially for Auckland, are a topic unto itself. James Watson's brief arguments that trams influenced land values and the contours of local politics certainly require deeper research, and such work may reshape the way we understand the evolution of New Zealand's urban landscapes. $^{20}$

\section{Local Histories, Urban Geography, and the Railway}

Local historians have readily incorporated the railway into their narratives and analyses. A good example is provided by a history of my hometown, Raumati Beach on the Kapiti Coast. It is hard to live there without being conscious of the railway, from heavy freight trains and electrified commuter units rumbling along the North Island Main Trunk (NIMT) on the eastern side of town to the miniature trains at Marine Gardens and the Wellington Tramway Museum in Queen Elizabeth Park. Just down the line from Raumati Beach is a town that has become part of New Zealand's railway folklore: Paekakariki, where for decades a large depot facilitated the exchange of steam and diesel locomotives for more powerful electric locomotives to haul trains on the difficult final stretch into Wellington. Today, the depot is occupied by the Kapiti Coast's most significant heritage organization, the railway preservation group Steam Incorporated. Fittingly, the Celebration History of the Kapiti District acknowledges the significant contribution made by the railways. A photograph of a locomotive in Paekakariki takes pride of place on the cover, and the history of both Raumati and Paraparaumu is contextualized with the observation that there was very little human activity in the area prior to the construction of the railway in the $1880 \mathrm{~s}$ - the trains came, and the town followed. ${ }^{21}$

This is true of local histories of many other towns too. To take four isolated examples from a very wide pool, the railway looms large for towns as diverse as Hamilton and Kaiapoi, or Lower Hutt and Taihape. David P. Millar frames the entire development of Lower Hutt in the 1870s around the arrival of the railway; beyond this chapter, the railway emerges to shape social interactions from sporting events to Lower Hutt's rivalry with neighbouring Petone. ${ }^{22}$ Railways feature as prominently in the history of Hamilton. The gradual rise of the town as a major junction from the late 1870 s cemented the railway as a prominent part of local discourse - and even before the railway arrived, the opening of a line to nearby Ngaruawahia was enough to excite Hamiltonians. ${ }^{23}$ Kaiapoi experienced a more fraught relationship, where 
the railway enters the narrative as part of a broader debate on the North Canterbury economy - would a railway to Christchurch threaten the local port, and should railways instead fan inland to serve the port rather than link with Christchurch? ${ }^{24}$ In the end, the railway to Christchurch was built, entering Kaiapoi social life and refocusing its economy.

The contribution of the railway to Taihape is even more central to its existence. Its centennial history emphasizes that Taihape's location was chosen in 1894 for its position where roads from Napier and Mataroa met the then under-construction NIMT at the 150-mile peg north of Wellington. ${ }^{25}$ Furthermore, this shaped Taihape's growth at the expense of previously established Moawhango - construction of the railway compelled shopkeepers in 1897 to shift to Taihape and Moawhango declined in importance while Taihape blossomed, home at one point to over four hundred railway staff. ${ }^{26}$ Socially and economically, the railway stands at the heart of the histories of towns such as these. However, as Ballantyne emphasizes, local histories are not without limitations. They 'often invoke an image of a fixed and stable closed place', when a better way of conceptualizing localities is as 'knot-like conjunctures' where local culture and identity interlock with global networks that move people, products, and culture between locations. ${ }^{27}$ Thus, although local histories show the prominence of railways to specific places, they do not provide an overview of sufficient breadth or complexity.

The prominence of railways in our local histories has failed to flow on to national historical accounts, despite international precedents. In Britain, the transformative role of the railway on town and city life has been thoroughly investigated. John R. Kellett provides detailed analysis of the topic, finding specifically that the railway redistributed land uses, contributed profoundly to property value and the location of manufacturing industries, and reshaped cities' internal traffic routes. ${ }^{28}$ An even more comprehensive account is by Jack Simmons, whose remarkable The Railway in Town and Country explores the relationship between railways and customers, the role played by the railway in the life of the Victorian age, and the diversity of these experiences. ${ }^{29}$ Unfortunately, Kellett and Simmons' conclusions cannot be applied to New Zealand, as Victorian Britain is not comparable for this purpose. Much more research is required before New Zealand can enjoy an equal understanding of how railways shaped the contours of daily life. British cities were well established and heavily populated and the countryside had been cultivated for centuries; New Zealand presented an untapped frontier developed in part by the railway. Many towns barely existed prior to the railway, and major settlements had no more than a brief pre-railway existence. Christchurch was only 13 years old when its first railway opened; Wellington experienced the longest period between founding and first railway, yet this was a mere three decades.

The most vigorous engagement with the role of railways in New Zealand's historical development has come from geographers. ${ }^{30}$ Not all have been thorough - railways appear surprisingly little in Alan H. Grey's historical geography, which is more valuable for his maps of railway expansion than for his very brief analysis. ${ }^{31}$ However, Eric Pawson's study of timespace convergence in New Zealand with an overview of the decreasing journey time between Dunedin and Auckland over 140 years is instructive and accessible. The railway network contributed considerably to travel time plummeting from twelve days at best in 1855 to fortyseven hours in 1909 when the completion of the NIMT 'revolutionised the north-south journey'. ${ }^{32}$ Travel between major centres could now be calculated in hours rather than days, with all the associated consequences for personal and commercial business. Pawson concludes with a series of implications of this convergence, including the rise of national identity, the economic boon, the implications for small towns bypassed by more direct networks, and the role of the state in transport services. ${ }^{33}$ These provide a particularly useful basis for further research. 
On a more theoretical level, Chris Harris provides a sophisticated trans-Tasman account, drawing upon Miles Fairburn's depiction of competing visions of Arcadia and Utopia in colonial New Zealand. Harris argues that one factor that gave the Australasian frontier 'a relatively Utopian cast was a close linkage between state railways and land development'. ${ }^{34}$ As Davis and Huttenback's striking data shows, Australasian colonial state expenditure was proportionately three times that of the average developed country, and not even the colonies' rapid growth and youth can explain this heightened investment as similar young regions had a much lower level of expenditure. ${ }^{35}$ The prominence of the central and provincial governments in railway building helps differentiate New Zealand from other young societies such as the United States, where federal land was given to private corporations for railway development. Prior to the maturation of automotive technology in the 1950s, Harris emphasizes that New Zealand 'formed something of an exception to usual Anglophone difficulties with rail, perhaps because of the strong role played by the state in their early development'. ${ }^{36}$ Town planning was linked to an 'entrepreneurial state railways department', though this came to the fore in the twentieth rather than the nineteenth-century, especially with regards to the Hutt Valley in the 1920s-50s and Porirua in the 1940s-70s. ${ }^{37}$

There is consequently a peculiar situation where the importance of the railway for social development has been recognized internationally and within the work of New Zealand's geographers and local historians, yet this has not been integrated into national history at the same degree of significance. This is partly for benign reasons, such as the realities of word limits and other constraints. Nevertheless, a phenomenon that is understood at the local level and has been repeated countless times nationwide has been largely left by the wayside. A phenomenon that is understood by geographers to compress space and time and to shape patterns of settlement remains standing on the platform. To use railway parlance, perhaps this is because geography and local history have been seen as something of a flag station for historians, stopped at only when required. The remainder of this article seeks to build upon the admirable trackbed formed by local histories and geographers, to show that the status of railways in New Zealand history is closer to that of a trunk route than a branch line.

\section{The Provincial 'Prehistory' of Railways}

New Zealand presents a unique case study of railway development, and of railways as a tool of colonization, state-building, and politics. Philip Ross May observed in 1975 that '[f]rom the 1870 s colonial politics often ran on railway tracks'. ${ }^{38}$ The point is not only long overdue for elaboration, but also for expansion. New Zealand's engagement with railways did not begin with the 1870 s, and politics often ran on railway tracks - typically of imagination or foresight rather than a permanent way - before the rise of Julius Vogel and his Great Public Works Policy (GPWP). The existing literature has a habit of taking 1870 as a starting point. This is perhaps to be expected in general works, but more surprising from specialist ones. ${ }^{39}$ Atkinson provides only a brief discussion of railways in the $1850 \mathrm{~s}-60 \mathrm{~s}$ as a prelude to the GPWP, overshadowed by a painting of the first train journey in Canterbury. ${ }^{40}$ Watson, who locates railways within the broader webs of New Zealand and global transportation, similarly is more concerned with the GPWP and its aftermath, as railways and tramways fanned across New Zealand. ${ }^{41}$ His assertion that steam locomotion 'gained premier status on land from the 1870s' can only be sustained through a narrow emphasis on physical construction, in ignorance of popular imagination, political debate, and public pressure. ${ }^{42}$ Disappointingly, in Rosslyn Noonan's history of the Public Works Department, her brief discussion of provincial public works and the establishment of the central government's department does not even mention the existence of provincial public works departments, let alone contextualize the creation of the central department with reference to the workings of provincial departments and the formation of local boards. ${ }^{43}$

Journal of New Zealand Studies NS16 (2013) 131-146 
Unlike any other settler society, no organized settlement occurred anywhere in New Zealand until after railways were invented. When the Treaty of Waitangi was signed in 1840, England was about to enter 'Railway Mania', years of rampant speculative railway expansion that were most pronounced in the mid-1840s. ${ }^{44}$ The vast bulk of New Zealand colonists migrated from Britain during or after this period of history, when railway lines fanned out from British towns into the countryside, often with little regard for their long-term economic viability. Freeman's exploration of railways and the Victorian imagination unfortunately stays grounded in Britain and, except for a very brief mention of imperial and European railways in the epilogue, it does not follow the flows of colonists to their new homes abroad. ${ }^{45}$ It is time the links between railways and the early colonial New Zealand imagination are explored. To New Zealand's first Pākehā settlers, the railway was a normal and desirable aspect of modern society. By contrast, even New Zealand's nearest neighbours, the six Australian colonies, were founded before the flourishing of the railway era.

Railways figured prominently in settler visions of the future. It is certainly a mistake to say, as R.P. Hargreaves does, that railways in the 1860 s were 'unimportant', and although Ballantyne is not wrong to note that New Zealand was an 'essentially littoral society' in 1860 in which 'the sea was the highway', the imagination of settlers turned to the railway. ${ }^{46}$ The sea, after all, could not open up inland regions and maritime transportation was far more subject to the vagaries of weather than rail. James Coutts Crawford, a prominent Wellingtonian of numerous talents, was quick to emphasize that '[s]teamers can never replace railroads for opening out the interior of a country nearly destitute of navigable rivers, and steamers must be fed by roads, bringing them supplies of produce, therefore, ceteris paribus, why not make the best description of road?' ${ }^{47}$ Crawford of course meant a railway, and he urged his readers not to be 'content to leave the development of the country to our children'. ${ }^{48}$ Settlers like Crawford knew that railways could not be established immediately, but they were also impatient for progress. The absence of physical railways should not be taken as implying an absence of a desire for them.

Even so, railways in the provincial period remain poorly understood. The two provincial railways opened prior to 1870 by Canterbury and Southland have been chronicled - to a pleasing degree of scholarly merit - by authors for the enthusiast market, while Nelson's private, horse-drawn Dun Mountain Railway is central to Mike Johnston's history of the Nelson mineral belt. ${ }^{49}$ However, most literature, scholarly or enthusiast, does not seriously engage with pre-1870 railways or proposals for railways. Exceptions are rare: in the enthusiast domain, Rob Merrifield's history of Marlborough's railways chronicles the lofty unfulfilled ambitions of the provincial council in the $1860 \mathrm{~s}$, while the second volume of the History of Canterbury is a scholarly example that places due emphasis on railways and deserves replication. ${ }^{50}$ J.A. Dowie admirably does not assume 1870 was year zero for railways, but his analysis of the prehistory is superficial, explaining the geographic origins of provincialism while failing to clarify the 'significant efforts' of provincial councils in railway construction or the 'pitfalls present' that some encountered. ${ }^{51}$

Geography of course explains some aspects of New Zealand's railway development, but it was also informed by ideas imported from Britain and the actions of provinces. Even W.P. Morrell, whose history of the provincial system is of such high quality that it remains authoritative over eighty years since it was first published, does not engage substantially with railways. His discussion of the relationship between provincialism and railways before Vogel is limited to curious asides about Canterbury's bold construction and difficulties in Marlborough and Southland. ${ }^{52}$ Morrell's limited engagement does nothing to indicate the 
importance of railways in the provincial era. Nor do his observations of Marlborough and Southland sufficiently emphasize their importance in the evolution and demise of the provincial system. My recent work demonstrates that these provinces' failings had greater consequences for provincialism than previous historians have assumed. ${ }^{53}$

Railways were conflated with ideas of civilization and sat at the heart of the progress industry. To New Zealand's settlers, drawn predominantly as they were from Victorian Britain, railways represented the pinnacle of scientific achievement and redefined the relationship between time and space; anywhere without a railway was, to the Victorian conceptualization, a backwater. ${ }^{54}$ Atkinson notes that from the 1870s the railway was a fixture of daily life representing innumerable possibilities. ${ }^{55} \mathrm{He}$ does not extend this analysis back to previous decades when the possibilities of the introduction of railways entertained settler minds and shaped their vision of what their new colony ought to become. William Gisborne, who later served as the first Minister of Public Works in 1870-71, articulated the Victorian faith in railways to the Auckland Mechanics' Institute in May 1852. 'Steam furnishes man with a power which almost transcends belief', he told his audience, citing it as a creator of wealth capable of further empowering humanity. 'The present gigantic [global] projection of railways appears to know no abatement ... difficulty after difficulty - the lofty mountain, the treacherous swamp, the broad, deep river - all disappear before enterprise and skill'. ${ }^{56}$

Surely it was only a matter of time before such projections came to New Zealand. William Long Wrey in Nelson, later associated with the Dun Mountain Railway, was touting railways in 1853 as no less than 'the greatest social revolution ever experienced since the world was created ${ }^{57}$ His proposal for a railway linking Nelson and other settlements on the east coast of Tasman Bay with the Waimea Plains was not seriously considered at the time. Canterbury, on the other hand, contemplated significant projects almost from the moment it was founded. Nothing hindered the province's growth more than the Port Hills separating Christchurch and the Canterbury Plains from Lyttelton; nothing, according to a commission appointed by the provincial council in 1854, could resolve the difficulty more effectively than a railway tunnel. ${ }^{58}$ Thus the die was cast. By 1860, Canterbury, prosperous from land sales, approved a $£ 300,000$ loan to construct the railway. The extent to which the tunnel debate overtook the young community is best reflected in the fact that today's venerable old newspaper of Christchurch, the Press, was founded not as a respectable journal of record, but as a means for James Edward FitzGerald, the province's first superintendent, to savage the railway and its supporters, led by current superintendent William Sefton Moorhouse. ${ }^{59}$

Railway proposals became a fixture of the provincial world during the 1860 s. As Canterbury successfully dug through the Port Hills, Southland faltered with an ill-advised wooden railway. This bizarre experiment reflects the manner in which railways became tied to provincial identity. Southland, smarting over the fact it separated from Otago in April 1861 just before the discovery of gold, sought to enrich itself by diverting the goldfields trade from Port Chalmers to Bluff by building a railway to the Lakes District. With time of the essence and iron for rails in short supply, it fell back on an untried wooden system and soon found the experiment literally crumbling as the track splintered beneath trains and the province went bankrupt. ${ }^{60}$ In Wellington, Crawford urged his railway proposals be pursued promptly once he heard of Marlborough's proposals: '[i]s the Old Province of Wellington to show less enterprise than its younger sister?' ${ }^{61}$ Canterbury's railway, upon the opening of the first section, was celebrated as a provincial achievement within an international empire. Moorhouse's speech for the occasion looked not to a national future but to an intra-provincial network; amongst the many toasts to Canterbury, Britain, and their leading personalities, the 
only hint of 'New Zealand' was a toast to Governor George Grey. ${ }^{62}$

Truly the archipelago was a multiplicity of identities and polities. Transport was central to who they were and what they might become. As Ballantyne notes, the weakness of transport networks had political consequences, playing a major role in the creation of new provinces, and this point deserves elaboration. ${ }^{63}$ New Zealand's internal divisions were created and its regional identities cemented, to a significant degree, by debate over the provision of transport facilities. Marlborough divorced from Nelson in November 1859, with its first newspaper established in January 1860. The Marlborough Press quickly became home to a discussion on railways and the province's future. This reflected a discussion already well developed in the community, even though Marlborough was home to only 1,151 people. ${ }^{64}$ Most contributors favoured railways, and editorials - the only source of advocacy in Marlborough outside personal persuasion - cajoled support and quelled objections. ${ }^{65}$ 'Roads', wrote one contributor, meaning both highways and railways, 'must, of course, exist in every country emerged from barbarism'. ${ }^{66}$

If there was a proposal worth making, it was worth including the railway, and suggestions swept the country. Crawford's vision for Wellington was a vast provincial network to exploit timber resources, while another writer envisaged an early version of the NIMT linking Auckland and Wellington as part of his proposal to make Ngaruawahia the capital of New Zealand. ${ }^{67}$ Auckland Province in 1863 approved a railway south to the Waikato and began construction in 1865 , but by 1867 it collapsed amidst severe allegations of financial incompetence. ${ }^{68}$ This railway, routinely ignored by any discussion suggesting only the South Island had railways in the $1860 \mathrm{~s}$, speaks to numerous topics. It was envisaged as a tool of securing peace, of subduing and 'civilizing' Māori resistance to Pākehā, and of promoting provincial prosperity and development. The fact it was not completed until the Vogel era does not negate its significance in illustrating the attitudes or goals of settlers and it deserves much more examination than it has received.

Also grossly overlooked within the existing literature are bush tramways. These rough and often improvised lines linked industries first with ports and then with permanent railways, or connected raw materials with industrial plants, such as timber reserves with a mill. They crisscrossed New Zealand, and although they became most closely associated with the timber industry, they first boomed in Westland during the gold rush of the late 1860s as the thick forest made communication difficult. These lines were often ephemeral, rising and falling in line with the diggings, and they were not expected to provide the all-purpose heavy haulage of a railway. Nonetheless, a network of private lines quickly developed on the West Coast, encouraging a speculative tramway bubble, and Philip Ross May is attentive to them in his magisterial history of the West Coast rushes. ${ }^{69}$ The same cannot be said of other historians. For instance, bush tramways are conspicuous by their near-total absence in Stevan EldredGrigg's recent account of New Zealand's gold rushes, while Watson's history of New Zealand transport bafflingly mentions them just once and without any analysis. ${ }^{70}$ Atkinson's Trainland likewise all but ignores these close relatives of the railway. Paul Mahoney has fortunately sought to rectify this situation, but much more work is necessary before the bush tram, once common throughout New Zealand, takes its place in historical scholarship. ${ }^{71}$ Bush tramways however undermine the Vogel-centric paradigm. Although they were influenced by it - they connected with railways and sometimes used cast-off locomotives and wagons - they were privately operated, developed to serve business needs, had their own unique relationship with rural settlers, and operated in a distinctive sphere. 1870 does not loom so large as a turning point in their history. 
Railways, Statecraft, and Society: The Vogel Boom and Beyond

Historians and enthusiasts alike have unfairly ignored provincial railways, but expanded and new fields of research also exist after 1870 . New Zealand provides a unique model for the study of colonial railway development and the interplay between state, society, and rail. This is not to suggest that the railway was not used as a tool of colonial statecraft elsewhere. It was. This occurred across the board, from Canada to Argentina, India to Australia. ${ }^{72}$ The United States has accrued a large amount of literature exploring the intersection of railways, politics, and society, including William G. Thomas's significant exploration of how Northern and Southern railways interacted with slavery, the US Civil War, and competing ideas of modernity. ${ }^{73}$ Sarah H. Gordon's Passage to Union is an even more broad treatment of how the '[e]xchange of goods and people, ideas and cultures all took place in the context of railroad transport' until the interwar period, and with 'exchange as the society's defining principle, the railroads held a prominent position in defining the social order' ${ }^{74}$ No doubt part of the reason railways feature more prominently in the literature of other countries is that they tend to be large; interstate and transcontinental railways were massive projects tied to national development and achievement. New Zealand, by contrast, is so small that it featured the world's only coast-to-coast urban tram line - Auckland's Onehunga route. However, the affliction of 'artificial' distance due to the union of rugged and difficult terrain with inclement weather gives otherwise short distances in New Zealand a similar drama to the vast North American and Australian landscapes.

Railway development in New Zealand deserves to be understood on its own terms. Atkinson has obviously laid the groundwork with his discussion of New Zealand as a railmaking state. He argues that 'rail was an engine of colonisation ... follow[ing] the American model of opening up supposedly uninhabited wildernesses'. ${ }^{75}$ Vogel notably based components of the GPWP upon American practice. ${ }^{76}$ Yet the comparison is overstated. New Zealand invested an average of $£ 1.97$ per person per year on public works during 1870-1900, of which $£ .87$ was on railways alone; the Pacific region of the US, by contrast, invested an average of merely $£ .17$ (state and federal expenditure combined) on all public works. ${ }^{77}$ There is a case for New Zealand's distinctiveness. The Australasian colonies were distinct from the rest of the world in the level of their investment, and after 1870 New Zealand was distinct from its trans-Tasman neighbours in its national (rather than state) framework for railway construction. Australian railways in many cases advanced one state's interests against another, and the lure of a trans-continental railway even served as a pre-federation promise to Western Australia. By contrast, Vogel's centralization of policy did not support provincialism or secure the loyalty of individual provinces, but undermined them.

Railways have primarily been understood for their economic function, even though they served a much wider purpose. Economic accounts are valuable but too often have been generalized, mainly due to a macroeconomic emphasis. Muriel F. Lloyd Prichard limits her discussion largely to expenditure figures and a generalized account of Vogel's public works programme. ${ }^{78}$ Despite a brief observation that by the 1890 s most major centres were linked and 'branch lines stretched out into some of the back country', the significance for economic growth is not explored. ${ }^{79}$ J.B. Condliffe highlights that public works such as railways made possible large-scale wheat farming in the early 1880 s and enabled the rise of the frozen meat trade. ${ }^{80}$ However, this is a peripheral point. Dowie and G.R. Hawke are most attentive. Railways appear throughout Hawke's general account; no doubt this is due in part to his previous work on railways in Britain. ${ }^{81}$ Dowie helps illuminate the wild optimism of the period and the failure to fully achieve an inter-urban trunk network through his study of the interconnections between railways, business, and politics in the 1870s and his exposition of the narrow economic concepts held by many politicians. ${ }^{82}$ Nonetheless, both focus on national economics and the railway system as a whole rather than understanding how its gradual, 
fragmented expansion shaped identities. Arnold provides a rare and telling case study from Taranaki that shows how freight rates caused conflict between railway and industry and influenced rural patterns of trade. ${ }^{83} \mathrm{~A}$ purely economic focus is much too limited to understand how the railway shaped society; due to 'flights of statistical ingenuity and manipulation, [railways'] role was reduced to a few percentage points of GNP'. ${ }^{84}$ Atkinson and Watson's books provide glimpses beyond statistics. The task now is for histories of colonial New Zealand to depict railways with the same significance they possessed to society at the time.

Railways deepened the reach of colonialism. This was partly achieved through the role of the GPWP in consolidating and centralizing Pākehā statehood. The argument that railways facilitated centralization is not new, but the manner in which they acquired a nation-building purpose - in contrast to their original provincial nature - needs to be examined in greater detail. Atkinson's engagement with provincialism is limited, simply suggesting railways 'helped central government outmuscle provincial rivals', while Morrell's argument wavers. ${ }^{85}$ Morrell argues that if the provinces were unable to play their forecast part in the GPWP (which they did not), 'their very existence would be in danger', yet later concludes that the GPWP - due to an emphasis on physical construction - did not greatly contribute to abolition. ${ }^{86}$ Much more than a few sentences are necessary to understand how five years of development under the GPWP shaped settler perceptions of provincialism and influenced their voting patterns in the $1875-76$ election, which was effectively fought over abolition. ${ }^{87}$ The gradual expansion of railways was the physical manifestation of the settler imagination of prior decades, and it naturally generated affection for the institution developing them at the expense of the multiplicity of institutions that, by and large, had not. Railways thus deserve stronger emphasis in any discussion of the evolution of New Zealand centralization or the rise in national identity.

The relationship of railways and Māori also warrants further attention. The first railways were built on land Pākehā had already acquired from Māori, but increasingly from 1880 the construction of new lines necessitated the purchase of Māoriland. Waitangi Tribunal reports have analysed some of the effects of railways upon Māori, especially in the form of public works takings, and Atkinson has already described how construction of the NIMT represented 'a series of assaults' on de facto Māori independence in the central North Island. ${ }^{88}$ However, Atkinson's account of railways and Māori is that of a general overview. Māori interactions with railways varied from region to region, iwi to iwi. This discussion remains under-developed and often locked up within Tribunal reports.

As I foreshadowed earlier with regards to Auckland's 1860s railway ambitions, the railway also figured within the Pākehā imagination of Māori. This attitude existed before the Vogel era, illustrated by the popular editorial belief during the New Zealand Wars that railways would be 'works of peace' that would stimulate the development of 'prosperous villages throughout the line on spots where at one time stood the pah [sic] of the savage' ${ }^{89}$ As the GPWP spread its tentacles across New Zealand, the NIMT was seen as 'settl[ing] once and forever the painful and long-continued separation between the races' ${ }^{90}$ Vogel himself had an eye on pacifying the North Island through public works, and increasingly emphasized this objective later in life. ${ }^{91}$ The Victorian racial encounter, already so admirably explored, possessed a strong railway component that had continuity across the 1870 divide.

The railway was more than just a tool of the colonial project that bolstered a centralized Pākehā government; it also helped shape the fledgling Pākehā society. Again, Atkinson's work is a valuable springboard, but it is not the final word - can there ever be such? - and he has a twentieth-century emphasis. In the early days of New Zealand's railways, trains were a site 
for discussions of morality. After Wellington's first railway opened to Lower Hutt in 1874, complaints soon appeared about passengers singing raucous, coarse songs such as 'John Brown's Body'. ${ }^{92}$ The mere fact trains were scheduled to run on Sunday generated controversy, filling columns of the press. Sunday trains in Canterbury in the 1870s operated only on the Lyttelton line; the absence of services on the other routes led Christchurch's Star to scowl that ' $[\mathrm{t}]$ he day of compulsory Sunday observance has long gone by'. ${ }^{93}$ Not everybody agreed. One letter writer in Taranaki felt the operation of Sunday trains constituted a 'perfectly unnecessary instance of Sabbath-breaking' and - with the smug superiority of one on a self-conscious civilizing mission - saw it as a poor example to Māori. ${ }^{94}$ This, it appears, was a debate generated by the railways, at least in some centres: one Aucklander took great exception to the Sunday debate, arguing that 'one never heard a word about Sunday travelling by the steamboats'. ${ }^{95} \mathrm{He}$ was writing in response to a meeting at the Young Men's Christian Association that called for a reduction in Sunday trains and complained about alleged disturbances to church services caused by railways. ${ }^{96}$ Issues of morality were not the only concern. One locomotive driver in Marlborough lamented that since the introduction of Sunday trains in his province, not only did he have to work seven days without a rest, but he also did not receive an increased wage for Sunday work like he would have in England. ${ }^{97}$ Thus the railway furnishes insights into moral norms and working conditions of colonial New Zealand.

Railways also evoked a sense of civic pride in young communities searching for identity. Multiple authors have touched on their significance to the wider community, especially J.D. Mahoney, but New Zealand lacks detailed research akin to Jeffrey Richards and John M. MacKenzie's global study. ${ }^{98}$ Richards and MacKenzie briefly note New Zealand stations, but primarily for architectural purposes. ${ }^{99}$ As they point out, 'station buildings mirror the development of the country'. ${ }^{100}$ Stations were a distinctive part of colonial life, sitting metaphorically, if not always physically, at the centre of towns throughout New Zealand. For many, the railway was the most tangible connection to the wider world and its station the most prominent government presence in the community. Even Kaiapoi, which had entertained doubts about the economic boon of railways, came to define itself by its railway. In the $1890 \mathrm{~s}$, plans for a new railway station were made, and when they were finally realized in 1904, the new building was the first substantial example of the central government's presence in the town. $^{101}$

Questions remain. What political role did stations play? Atkinson, for instance, briefly notes their use for politically related public welcomes and ceremonies, but gives no further analysis. ${ }^{102}$ Electioneering, nationalism, localism, and other major civic displays took place on platforms from Opua to Bluff. What other sorts of exchanges took place on station platforms? How did the location of stations, often the most important building in a town, influence the layout and commercial character of towns across New Zealand? How did insistent timetables and 'railway time' affect communities? Eric Pawson has established that the telegraph, not railways, were the prime justification for standardizing New Zealand's time in 1868, but railways also played a role in the adoption and adherence of standard time. ${ }^{103}$ Timetables, after all, enforced punctuality; the New Zealand Herald editorialized that prior to the inauguration of the railway, punctuality was 'a virtue more honored [sic] in the breach than the observance by a large proportion of the Auckland public'. ${ }^{104}$

For smaller communities, what were the consequences of opening or closing a station? Richards and MacKenzie, in discussing the twentieth-century contraction of New Zealand's railways, argue that the closure of 'small rural stations ... destroy[ed] the role of small 
stations in the community'. ${ }^{105}$ This should be extended back to understand what this role was, how it began, and how it evolved. If we are interested in microhistories, how did stations feature within personal stories of excitement, heartbreak, and homecoming? The airport terminal of today is well removed from the hustle and bustle of the nineteenth-century platform. These sorts of questions warrant more detailed study. Mahoney alludes to many of them, but substantiates them only with isolated examples rather than thorough analysis and his book primarily emphasizes architecture and train operations. ${ }^{106} \mathrm{We}$ possess too little detailed research about how railway stations shaped community life, whether this was consistent or variable between regions - and, at a larger level, how decisions about railway routes shaped patterns of settlement, either cursing nebulous communities to obscurity or promoting them to prominence.

\section{Conclusion: Stopping All Stations?}

The importance of railways has not been sufficiently recognized. Railways intersected with almost every aspect of nineteenth-century life in New Zealand, yet this is often not made apparent. The most focused attention has often come from railfans and local historians with whom academic engagement has been limited, or from geographers with whom greater interdisciplinary engagement is desirable. Some historians - Atkinson and Watson the standard bearers - have laid the groundwork for a more detailed and rigorous understanding, and enthusiast literature contains a wealth of useful technical information. I have indicated a number of fields warranting further attention, with tentative conclusions. Railways of the provincial era in particular have been ignored and downplayed. This 'prehistory' is important not just to contextualize the Vogel boom and beyond, but to gain an insight into settler life and how Pākehā viewed the present and future. Railways figured prominently and potently within the settler imagination. From 1870, coverage has been better, but I have noted numerous directions forwards: the connection between railways, politics, and Māori looms as especially significant, but also important are the social function of stations and debates over morality. A fixation upon physical construction alone neglects the wider relevance and importance of railways. Trains served more than a purely economic function, and to reduce them to simply a few statistical measures is a serious mistake.

This article is not exhaustive. The environmental consequences of the railway cannot be understated and Atkinson is merely stating what should have been obvious when he writes that 'rail accelerated the destruction of New Zealand's natural environment'. ${ }^{107}$ Yet, surprisingly, even prominent environmental histories do not seriously engage with the effects of railways. ${ }^{108}$ The construction of railways cut through the New Zealand landscape; it enabled vast exploitation of natural resources such as forests; it demanded resources of its own, especially coal; it spewed pollutants back into the air - by no means as terrible a polluter as the car or plane, but still a contribution to environmental degradation.

Further examples of railway's role in shaping New Zealand must await other historians. Although enthusiasts have carefully studied the history of the railway, it needs to be examined by historians and integrated into wider narratives. It is unreasonable to expect enthusiasts to do this - their audience and emphases are different. Nostalgic narratives of majestic trains trundling through pretty landscapes have their place, but we must move away from the currently under-developed scholarly narrative of railways as a largely economic force unleashed by Vogel in 1870. The use of 1870 as a starting point should be rejected and replaced by a more nuanced understanding of how many themes originated earlier in New Zealand's colonization and continue well past Vogel's day. We need to stop all stations and interrogate how railways influenced and were influenced by nineteenth-century New Zealand.

Journal of New Zealand Studies NS16 (2013) 131-146 
${ }^{1}$ This article began life as a presentation at the New Zealand Historical Association's conference at the University of Waikato in November 2011 and has evolved considerably since. My thanks are due to Stuart Macintyre (to whom I owe the idea of referring to pre-Vogel railway development as a 'prehistory'); Patricia Grimshaw, and Len Richardson for their time, comments, insights, and proofreading; the anonymous reviewers for invaluable suggestions; Charlotte Whild for her proofreading and patience; Lena Duffin for her urban geography suggestions; and to everyone at the conference who offered comments, advice, and encouragement. I did not expect such warm interest in my presentation, and follow-up questions at later conferences gave me the necessary enthusiasm to convert the paper into an article.

${ }^{2}$ Michael Freeman, Railways and the Victorian Imagination, (New Haven and London: Yale University Press, 1999), 19.

${ }^{3}$ James Belich, Replenishing the Earth: The Settler Revolution and the Rise of the Anglo-World, 1783-1939 (Oxford: Oxford University Press, 2009), 185.

${ }^{4}$ Peter Gibbons, 'The Far Side of the Search for Identity: Reconsidering New Zealand History', New Zealand Journal of History 37, 1 (April 2003): 39.

5 Tony Ballantyne, 'On Place, Space and Mobility in Nineteenth-Century New Zealand', New Zealand Journal of History 45, 1 (April 2011): 55. This article also appears as chapter fourteen in Tony Ballantyne's Webs of Empire: Locating New Zealand's Colonial Past (Wellington: Bridget Williams Books, 2012).

${ }^{6}$ John Cookson, 'How British? Local Government in New Zealand to c.1930', New Zealand Journal of History 41, 2 (October 2007): 143-60.

7 Rollo Arnold, New Zealand's Burning: The Settlers' World in the Mid 1880s (Wellington: Victoria University Press, 1994), 194. I accept Arnold's argument that coastal shipping has been considerably under-studied, but making this argument by comparing it to the inclusion of railways within New Zealand historiography is unnecessary and inaccurate.

${ }^{8}$ Erik Olssen, Building the New World: Work, Politics and Society in Caversham, 1880s-1920s, (Auckland: Auckland University Press, 1995), chapter six; Erik Olssen and Jeremy Brecher, 'The Power of Shop Culture: The Labour Process in the New Zealand Railway Workshops, 1890-1930', International Review of Social History 37, 3 (December 1992): 350-75; J.D. Henning, 'Government Railwaymen and Industrial Relations, 1884-1894' (MA thesis, University of Auckland, 1984); and the links between railways, coal mining, and mining unionism contextualise Len Richardson, Coal, Class and Community: The United Mineworkers of New Zealand, 1880-1960 (Auckland: Auckland University Press, 1995).

${ }^{9}$ David Hamer, 'The Agricultural Company and New Zealand Politics', Historical Studies Australia and New Zealand 10, 38 (1962): 141-64; John Rosanowski, 'The West Coast Railways and New Zealand Politics, 18781888', New Zealand Journal of History 4, 1 (1970): 34-53; John Rosanowski, 'Politics and Railways: The Midland Line, 1887-1918', in Philip Ross May, ed., Miners and Militants: Politics in Westland, 1865-1918, (Christchurch: Whitcoulls, 1975), 80-100; Russell Stone, 'The Thames Valley and Rotorua Railway Company Limited, 1882-9: A Study of the Relationship of Business and Government in Nineteenth Century New Zealand', New Zealand Journal of History 8, 1 (1974): 22-43.

${ }^{10}$ J.A. Dowie, 'The Course and Character of Capital Formation in New Zealand, 1871-1900', New Zealand Economic Papers 1, 1 (1966): 38-58.

${ }^{11}$ David Hamer, The New Zealand Liberals: The Years of Power, 1891-1912 (Auckland: Auckland University Press, 1988), 137-40.

12 Neill Atkinson, Trainland: How Railways Made New Zealand (Auckland: Random House, 2007).

${ }^{13}$ Ballantyne, 'On Place', 57.

${ }^{14}$ David Leitch and Brian Scott, Exploring New Zealand's Ghost Railways, rev. ed. (Wellington: Grantham House, 1998 [1995]).

${ }^{15}$ Good examples include David Leitch, Steam, Steel and Splendour (Auckland: HarperCollins, 1994); Tony Hurst, Farewell to Steam: Four Decades of Change on New Zealand Railways (Auckland: HarperCollins, 1995).

16 W.G. Lloyd, Register of New Zealand Railways Steam Locomotives 1863-1971 (And Beyond), $2^{\text {nd }}$ ed. (Dunedin: Otago Railway and Locomotive Society, 2002 [1974]); T.A. McGavin, Steam Locomotives of New Zealand, Part One: 1863 to 1900 (Wellington: New Zealand Railway and Locomotive Society, 1987); E.J. McClare, Steam Locomotives of New Zealand, Part Two: 1900 to 1930 (Wellington: New Zealand Railway and Locomotive Society, 1988) and Steam Locomotives of New Zealand, Part Three: 1930 to 1971 (Wellington: New Zealand Railway and Locomotive Society, 1991); Sean Millar, From A to Y Avoiding I: 125 Years of Railway Motive Power Classification in New Zealand (Auckland: Sean Millar, 2001); Eric Heath and Bob Stott, companion volumes Classic Steam Locomotives of New Zealand and Classic Railcars, Electric and Diesel Locomotives of New Zealand (Wellington: Grantham House, 1993).

${ }^{17}$ Examples of such books are multitudinous and impossible to list. The leading history of the national network is Geoffrey B. Churchman and Tony Hurst, The Railways of New Zealand: A Journey Through History (Auckland: Harper Collins Publishers New Zealand, 1990). Notable examples of histories of individual lines 
include K.R. Cassells, Uncommon Carrier: The History of the Wellington and Manawatu Railway Company, 1882-1908 (Wellington: New Zealand Railway and Locomotive Society, 1994); J.A. Dangerfield and G.W. Emerson, Over the Garden Wall: Story of the Otago Central Railway, $3^{\text {rd }}$ ed. (Dunedin: Otago Railway and Locomotive Society, 1995 [1962]); Rob Merrifield, Beyond Dashwood: A History of the Railway in Marlborough (Wellington: New Zealand Railway and Locomotive Society, 1990); A.R. Tyrrell, Catlins Rail: The Story of the Catlins River Branch Railway, 1879-1971 (Owaka: Catlins Historical Society, 1996); and Lois Voller, Rails to Nowhere: The History of the Nelson Railway (Nelson: Nikau Press, 1991).

18 Ballantyne, 'On Place', 61.

${ }^{19}$ The current standard work, written from an enthusiast perspective but to a high degree of quality, is Graham Stewart, The End of the Penny Section: When Trams Ruled the Streets of New Zealand, rev. ed. (Wellington: Grantham House, 1993 [1973]).

${ }^{20}$ James Watson, Links: A History of Transport and New Zealand Society (Wellington: GP Publications, 1996), 137,148 .

${ }^{21}$ Olive Baldwin, ed. The Celebration History of the Kapiti District: 100 Years Plus, (Paraparaumu: Kapiti Borough Council, 1988). The importance of the railway to Paraparaumu's genesis is stated by Geoff Thompson, 'The Kapiti Coast - Development to Maturity', 57-59.

22 David P. Millar, Once Upon a Village: A History of Lower Hutt, 1819-1965 (Wellington: New Zealand University Press, 1972), chapter seven. See also 88-90 for the railway's role in cementing the Hutt as the centre of Wellington horseracing against a rival Island Bay racetrack, and 92 for the location of the railway workshop (and subsequently other industry) as the origin of rivalry with Petone.

${ }^{23}$ H.C.M. Norris, Settlers in Depression: A History of Hamilton, New Zealand, 1875-1894, (Auckland and Hamilton: Paul's Book Arcade, 1964), especially chapter eleven. For Ngaruawahia festivities - and then the jubilation when the railway reached Hamilton - see 35-38.

${ }^{24}$ Pauline Wood, Kaiapoi: A Search for Identity, (Rangiora: Waimakariri District Council, 1993), 93-98.

${ }^{25}$ Anne Potaka and Jackie Eustace, 'Establishment', in Denis Robertson, ed. 1894-1994: '... Give Me Taihape on a Saturday Night', ed. Denis Robertson (Waikanae: Heritage Press, 1995), 25.

${ }^{26}$ Vivienne Bird, 'The Main Trunk Line', in 1894-1994, 36, and 38.

${ }^{27}$ Ballantyne, 'On Place', 59, 61.

${ }^{28}$ John R. Kellett, Railways and Victorian Cities (London: Routledge, 1979 [1969]),15-17.

${ }^{29}$ Jack Simmons, The Railway in Town and Country, 1830-1914 (Newton Abbot: David and Charles, 1986).

${ }^{30}$ An early example is Kenneth B. Cumberland and R.P. Hargreaves, 'Middle Island Ascendant: New Zealand in 1881', New Zealand Geographer 11, 2 (October 1955): 115-17.

${ }^{31}$ Alan H. Grey, Aotearoa and New Zealand: A Historical Geography (Christchurch: Canterbury University Press, 1994), 26-31.

${ }^{32}$ Eric Pawson, 'Time-Space Convergence in New Zealand, 1850s to 1990s', New Zealand Journal of Geography 94, 1 (October 1992): 16.

${ }^{33}$ Ibid., 17-18.

${ }^{34}$ Chris Harris, Roads, Railways and Regimes: Why Some Societies are Able to Organise Suburban Public Transport - and Others Can't (Griffith University: Urban Research Program Research Paper 14, October 2007), 9.

${ }^{35}$ Lance E. Davis and Robert A. Huttenback, Mammon and the Pursuit of Empire: The Political Economy of British Imperialism, 1860-1932, (Cambridge: Cambridge University Press, 1986), 127-29.

${ }^{36}$ Harris, Roads, Railways and Regimes, 10.

${ }^{37}$ Ibid., 41.

${ }^{38}$ Philip Ross May, 'Preface', in Philip Ross May, ed., Miners and Militants: Politics in Westland, 1865-1918, ed. Philip Ross May (Christchurch: Whitcoulls, 1975), $x$.

${ }^{39}$ Even James Belich, whose general history gives more sophisticated attention to railways than the average text, writes as if railways had no significance in New Zealand until 1870. See Making Peoples: A History of the New Zealanders From Polynesian Settlement to the End of the Nineteenth Century, (Auckland: Penguin Books, 1996), 352.

${ }^{40}$ Atkinson, Trainland, 26-28.

${ }^{41}$ Watson, Links, chapter three.

${ }^{42}$ Ibid., 94.

${ }^{43}$ Rosslyn J. Noonan, By Design: A Brief History of the Public Works Department Ministry of Works 1870-1970 (Wellington: A.R. Shearer, Government Printer, 1975), 1-13.

${ }^{44}$ For more, see Henry Grote Lewin, The Railway Mania and its Aftermath, 1845-52, rev. ed., (Newton Abbot: David and Charles, 1968 [1936]).

${ }^{45}$ Freeman, Railways and the Victorian Imagination, 241-42.

${ }^{46}$ R.P. Hargreaves, 'The Golden Age: New Zealand About 1867', New Zealand Geographer, 16, 1 (April 1960): 
16; Ballantyne, 'On Place', 57.

${ }^{47}$ James Coutts Crawford, Remarks Upon Railways, Suggesting the Opening of a Timber Trade in the Province of Wellington (Wellington: Spectator Office, 1861), 11.

${ }^{48}$ Ibid.

${ }^{49}$ Mike Johnston, High Hopes: The History of the Nelson Mineral Belt and New Zealand's First Railway (Nelson: Nikau Press, 1987); W.A. Pierre, Canterbury Provincial Railways: Genesis of the NZR System (Wellington: New Zealand Railway and Locomotive Society, 1964); J.O.P. Watt, Southland's Pioneer Railways 1864-1878 (Wellington: New Zealand Railway and Locomotive Society, 1965).

${ }^{50}$ Merrifield, Beyond Dashwood, especially 13-15; W.J. Gardner, ed., A History of Canterbury, vol. II: General History, 1854-65 and Cultural Aspects, 1850-1950, (Christchurch: Whitcombe and Tombs, 1971).

${ }^{51}$ J.A. Dowie, 'Business Politicians in Action: The New Zealand Railway Boom of the 1870s', Business

Archives and History 5, 1 (1965), 33, 39-42.

${ }^{52}$ W.P. Morrell, The Provincial System in New Zealand, 1852-76 (Christchurch: Whitcombe and Tombs, 1964 [1932]), 113, 139-40, 144-46.

${ }^{53}$ André D.E. Brett, 'The Great Kiwi (Dis)Connect: The New Provinces Act of 1858 and its Consequences', Melbourne Historical Journal 40 (2012): 138-44.

${ }^{54}$ Freeman, Railways and the Victorian Imagination, 57-82. passim.

${ }_{55}$ Atkinson, Trainland, 138.

${ }^{56}$ New Zealander, May 22, 1852, 3

${ }^{57}$ Nelson Examiner, July 9, 1853, 6. Due to his role in the Dun Mountain Railway and a failed railway proposal in Marlborough in the mid-1860s, Wrey's name deserves to go down in New Zealand railway history infamy.

${ }^{58}$ The Report of the Lyttelton and Christchurch Road Commission, April 7, 1854, can be found in the supplementary section of the Lyttelton Times, April 22, 1854, 14.

${ }^{59}$ The editorial of the first edition of the Press, May 25, 1861, 2, makes the reason for its founding more than clear.

${ }^{60}$ I elaborate on this in 'Great Kiwi (Dis)Connect', 142-44.

${ }^{61}$ Crawford, Remarks Upon Railways, 12.

${ }^{62}$ Lyttelton Times, December 3, 1863, 4.

${ }^{63}$ Ballantyne, 'On Place', 57. Unfortunately, Ballantyne misidentifies Marlborough's separation from Nelson as occurring in 1869 , not 1859 , and overlooks the two examples of provincial separation where transportation featured most prominently - Southland's ill-fated divorce from Otago, 1861-70, and Westland's separation from Canterbury, first as a county in 1868 and a full province in 1873.

${ }^{64}$ A.D. McIntosh, ed. Marlborough: A Provincial History (Christchurch: Capper Press, 1977 [1940]), 208.

${ }^{65}$ For example: Marlborough Press, January 6, 1860, 3; January 20, 1860, 3; April 14, 1860, 3; May 25, 1861, 2; June 8, 1861, 2; November 15, 1861, 2.

${ }^{66}$ Marlborough Press, January 20, 1860, 3.

${ }^{67}$ Crawford, Remarks Upon Railways; 'A Settler', The Waikato and Ngaruawahia, The Proposed New Capital of New Zealand (Auckland: Wilson and Burn, 1863).

${ }^{68}$ Daily Southern Cross, August 17, 1867, 3.

${ }^{69}$ Philip Ross May, The West Coast Gold Rushes (Christchurch: Pegasus Press, 1967 [1962]), 359-63.

${ }^{70}$ Stevan Eldred-Grigg, Diggers, Hatters, and Whores: The Story of the New Zealand Gold Rushes (Auckland: Random House, 2011 [2008]), 275, 356 with brief mentions on 275 and 356; Watson, Links, 88-89.

${ }^{71}$ Paul Mahoney, The Era of the Bush Tram in New Zealand, (Wellington: Transpress, 2004). For an admirable and detailed regional study that begins after the provincial era, see Bryon Somervell, Sawmills and Bush Tramways of the Rotorua District and the Urewera Blocks, $3^{\text {rd }}$ ed. (Rotorua: Bryon Somervell, 2009).

${ }^{72}$ For Argentina, see Raymond H. Pulley, 'The Railroad and Argentine National Development, 1852-1914', The Americas 23, 1 (July 1966): 63-75 and Paul B. Goodwin Jr, 'The Central Argentine Railway and the Economic Development of Argentina, 1854-1881', The Hispanic American Historical Review 57, 4 (November 1977): 61332. For India, see Manu Goswami, Producing India: From Colonial Economy to National Space (Chicago: University of Chicago Press, 2004), chapter three. For Canada, see A.A. den Otter, The Philosophy of Railways: The Transcontinental Railway Idea in British North America (Toronto: University of Toronto Press, 1997). For Australia, see C.C. Singleton and David Burke, Railways of Australia, (Sydney: Angus and Robertson, 1963), or see histories of specific state systems, of which notable treatments include Leo J. Harrigan, Victorian Railways to '62 (Melbourne: Victorian Railways Public Relations and Betterment Board, 1962); Robert Lee, The Railways of Victoria, 1854-2004 (Carlton: Melbourne University Press, 2007); John Gunn, Along Parallel Lines: A History of the Railways of New South Wales (Carlton: Melbourne University Press, 1989).

${ }^{73}$ William G. Thomas, The Iron Way: Railroads, the Civil War, and the Making of Modern America (New Haven and London: Yale University Press, 2011). Other examples include Albert Fishlow, American Railroads and the Transformation of the Antebellum Economy (Cambridge: Harvard University Press, 1965); Arthur M. Johnson 
and Barry E. Supple, Boston Capitalists and Western Railroads (Cambridge: Harvard University Press, 1967); and John Stover, American Railroads (Chicago: University of Chicago Press, 1997).

${ }^{74}$ Sarah H. Gordon, Passage to Union: How the Railroads Transformed American Life, 1829-1929 (Chicago: Ivan R. Dee, 1996), 347-48.

${ }^{75}$ Atkinson, Trainland, 22.

${ }^{76}$ See the financial statement of Julius Vogel in Appendices to the Journal of the House of Representatives, 1870, B-02, 13 .

${ }^{77}$ Lewis and Huttenback, Mammon, 128.

${ }^{78}$ Muriel F. Lloyd Prichard, An Economic History of New Zealand to 1939 (Auckland: Collins, 1970). The lengthiest discussions are of Vogel's policy on.124-27 and expenditure in the 1880s-90s on expanding communications, 149-51.

${ }^{79}$ Ibid., 150.

${ }^{80}$ J.B. Condliffe, New Zealand in the Making: A Study of Economic and Social Development, $2^{\text {nd }}$ ed. (London: George Allen and Unwin, 1959 [1936]), 38 and 154.

${ }^{81}$ G.R. Hawke, The Making of New Zealand: An Economic History (Cambridge: Cambridge University Press, 1985); Railways and Economic Growth in England and Wales, 1840-1870 (Oxford: Clarendon Press, 1970).

${ }^{82}$ Dowie, 'Business Politicians in Action', 32-56.

${ }^{83}$ Arnold, New Zealand's Burning, 215-19.

${ }^{84}$ Freeman, Railways and the Victorian Imagination, 18-19.

${ }^{85}$ Atkinson, Trainland, 22.

${ }^{86}$ Morrell, Provincial System, 221, 281.

${ }^{87}$ The prominence of abolition in the election is captured by J.L. Hunt, 'The Election of 1875-6 and the

Abolition of the Provinces' (MA thesis, University of Auckland, 1961).

${ }^{88}$ Atkinson, Trainland, 40.

${ }^{89}$ See New Zealand Spectator, August 13, 1864, 3, and Hawke's Bay Herald, February 20, 1864, 3.

${ }^{90}$ Otago Witness, August 31, 1878, 13.

${ }^{91}$ Raewyn Dalziel, Julius Vogel: Business Politician, (Auckland: Auckland University Press, 1986), 105-06.

${ }^{92}$ David Millar, Once Upon a Village, 73.

${ }^{93}$ Star, July 1, 1874, 2.

${ }^{94}$ Taranaki Herald, July 2, 1878, 2.

${ }^{95}$ New Zealand Herald, February 5, 1874, 3.

${ }^{96}$ Daily Southern Cross, January 24, 1874, 3.

${ }^{97}$ Marlborough Express, June 7, 1876, 5.

${ }_{98}^{98}$ Jeffrey Richards and John M. MacKenzie, The Railway Station: A Social History (Oxford: Oxford University Press, 1986). For New Zealand, see J.D. Mahoney, Down at the Station: New Zealand Railway Stations Remembered (Palmerston North: Dunmore Press, 1995) as well as Atkinson, Trainland, especially 162-69.

${ }^{99}$ Richards and MacKenzie, The Railway Station, 87-89.

${ }^{100}$ Ibid., 87.

${ }^{101}$ Wood, Kaiapoi, 158-59.

102 Atkinson, Trainland, 165.

${ }^{103}$ Eric Pawson, 'Local Times and Standard Time in New Zealand', Journal of Historical Geography 18, 3 (1992): 278-87. Contributions in the Press reveal that the railway factored into discussions about time standardisation, e.g. 25 November 1864, 2; 10 December 1867, 2 (editorial) and.3 (letter). The editorial of 10 December 1867 notes the confusion caused by railway time being fifteen minutes slower than Christchurch time, resulting in 'numbers of people flocking in full haste to the Railway-station, thinking they were late when at the same time they had fully a quarter-of-an-hour to spare'.

${ }^{104}$ New Zealand Herald, January 28, 1874, 3.

105 Richards and MacKenzie, The Railway Station, 89.

106 J.D. Mahoney, Down at the Station, especially chapter one. For instance, on page 8 he indicates the community role of railway stations with a 1924 example from Dunsandel in Canterbury, where the station staff posted rugby scores on the station door.

${ }^{107}$ Atkinson, Trainland, 25.

${ }^{108}$ For example, railway mentions are scant in Tom Brooking and Eric Pawson, eds, Environmental Histories of New Zealand, ed. Tom Brooking and Eric Pawson (South Melbourne: Oxford University Press, 2002). 